\title{
Introduction to the special issue on taxes and transfers
}

\section{Juan Carlos Conesa ${ }^{1}$ - Javier Pérez ${ }^{2}$ - Virginia Sánchez-Marcos ${ }^{3}$}

Published online: 9 November 2019

(c) The Author(s) 2019

Understanding the design and economic impact of tax and transfer systems is at the core of research in economics. There is a very broad set of topics that fall within this line of research, such as the impact of taxes and transfers on the behavior of individuals, households and firms, fiscal federalism, redistribution and inequality, and tax evasion. In this special issue on taxes and transfers, several relevant questions regarding these topics are addressed. The papers included in this special issue are aimed at improving our understanding of the microeconomic and macroeconomic implications of different taxes and transfers using state of the art methods.

It is challenging to quantify the impact of taxes and transfers on households' and firms' decisions. Sometimes, the introduction of a particular policy provides a natural experiment that economists can use to measure how individuals' decisions are affected. Ayuso, Jimeno, and Villanueva (2019) examine the incidence on household consumption of the introduction of tax incentives to retirement savings. They show that the overall amount of new saving in response to tax incentives is limited. However, savings' responses are very heterogeneous across age groups, with the largest decrease in consumption expenditure found for households between 46 and 55 years of age. With a similar approach, De la Rica and Gorjón (2019) assess whether a minimum income scheme (MIS) in the Basque Country delays entry into employment for recipients and the extent to which active policies for recipients are effective. Using administrative data of the universe of individuals registered in the public employment service, they find that the minimum income scheme does not delay entry into employment, although the impact differs from one demographic group to another. Furthermore, active labor market policies, in particular training, have a strong positive impact on finding a new job. In another paper, Almunia and Lopez-Rodriguez (2019) study how taxable income responds to changes in marginal tax rates, using as the main source of identifying variation in three large reforms to the Spanish personal income tax implemented in the period 1999-2014. The most reliable estimates of the elasticity

\footnotetext{
$凶$ Virginia Sánchez-Marcos virginia.sanchez@unican.es

1 Stony Brook University, Stony Brook, USA

2 Bank of Spain, Madrid, Spain

3 Universidad de Cantabria, Cantabria, Spain
} 
of taxable income (ETI) with respect to the net-of-tax rate for this period are between 0.45 and 0.64 . The ETI is about three times larger for self-employed taxpayers than for employees and larger for business income than for labor and capital income. The elasticity of broad income (EBI) is smaller, between 0.10 and 0.24 , while the elasticity of some tax deductions such as the one for private pension contributions exceeds one. These estimates are similar across a variety of estimation methods and sample restrictions and also robust to potential biases created by mean reversion and heterogeneous income trends. Finally, the last example of this type of approach to learn about the impact of tax policies that is included in this special issue is Artés, Botello, and Sánchez (2019). They use Google searches as a proxy for the consumer's willingness to buy in order to study the effect of the Spanish 2010 and 2012 VAT reforms. They use a regression discontinuity design and find a significant causal effect of the implementation date of the reform on Google searches of durable goods, but they do not find any effect on nondurable goods. Their results are in line with the previous theoretical and empirical evidence according to which tax reforms cause consumers to modify more their readiness to buy durable goods.

In order to learn about the aggregate effects, the general equilibrium impact, and the distributional and welfare consequences for individuals of different taxes and transfers, a quantitative dynamic macroeconomic model calibrated to the economy of interest is needed. As documented in Alves and Afonso (2019), the relationship between different types of taxes, aggregate consumption, and inequality across the OECD countries is really complex and deserves the attention of economists.

There is a long tradition among economists in using heterogeneous general equilibrium models to assess these implications. In this special issue, we include several papers that address important questions. Díaz-Giménez and Pijoan-Mas (2019) quantify the aggregate, distributional, and welfare consequences of investment expensing and progressivity in Hall and Rabushka type of flat-tax reforms of the US economy. Their findings suggest that moving toward a progressive consumption-based flat-tax scheme could achieve the goals of raising government income, stimulating the economy, and providing a safety net for the households that have been hit the hardest by the recession. Durceylan (2019) provides an efficiency comparison of ad valorem and unit taxes by allowing the distribution of firms to respond to changes in policy. This is done in a model with monopolistically competitive firms that are homogenous with respect to their productivity levels. Consumer preferences exhibit love for variety and allow firms to adjust their markups. She finds that an ad valorem tax is more efficient. Allowing for firm heterogeneity overturns this result at high revenue requirements. As the tax rate increases, ad valorem tax causes excessive exit of firms which makes the market more competitive. Hence, few surviving firms price lower by decreasing their markups. Lower prices decrease the tax revenue collected. As a result, under ad valorem tax regime higher consumer surplus is dominated by lower tax revenue. On the other hand, production is concentrated among relatively more productive firms. Thus, aggregate productivity is higher under ad valorem tax regime.

But dynamic macroeconomic models can also be used for the analysis of optimal taxation. This allows economists to go a step further within the public finance literature to find the optimal combination of taxes in order to raise a certain amount of public revenues. Conesa and Dominguez (2019) analyze the role of intangible 
capital investment in the timing of optimal capital income taxation. They perform a Pareto-improving Ramsey tax reform and compare the optimal paths of corporate and dividend taxes during the transition with and without intangible capital. They show that without intangible investment, optimal labor tax rates are roughly zero, while with intangible investment, optimal labor tax rates are about $13 \%$. Overall, the presence of intangible capital decreases substantially the magnitude of income redistribution, not only in the short run but also in the long run.

Importantly, in order to undertake quantitative work in macroeconomics and public finances, economists need to summarize the complicated structure of taxes in easyto-interpret and easy-to-use parametric functions. As formerly done in Gouveia and Strauss (1994) or Heathcote et al. (2017), among others, García-Miralles, Guner, and Ramos (2019) provide estimates of effective tax functions that capture the underlying heterogeneity of the data in a parsimonious way using recent data for Spain.

Finally, economists may think of tax and transfer systems as emerging from a political equilibrium. In this case, the interest in not only on the impact of taxes and transfers on individual's decisions, but also on how the distribution of the population determines the particular tax and transfer system that prevails in the economy. Mayoral and Esteban (2019) study majority voting over fiscal policies in a model in which, besides redistributing income, the government decides the composition of goods and services (education, health, law-and-order, etc.) provided to citizens. In addition, they tackle the problem of choosing the income tax function and the composition of public expenditure by assuming that the political process selects one of these issues as the salient one. Political controversy and vote focus on this issue exclusively. The other dimension is determined in a way so as to minimize objections (obtain consensus) among the voters. In the case in which the salient policy is the composition of public expenditure, they show that for each voted expenditure policy, there is a unique income tax function that attains consensus. The political process they model yields that the progressiveness of the income tax schedule depends on income inequality interacted with the elasticity of substitution of the goods provided in the market and those publicly provided.

We hope the articles in this special issue provide a flavor of the existing work in the frontier of research on the impact of taxes and transfers. While not exhausting all the potential topics, we are confident that we are covering many of the important areas and methodological approaches, and we are looking forward to continuing contributions in this area.

Open Access This article is distributed under the terms of the Creative Commons Attribution 4.0 International License (http://creativecommons.org/licenses/by/4.0/), which permits unrestricted use, distribution, and reproduction in any medium, provided you give appropriate credit to the original author(s) and the source, provide a link to the Creative Commons license, and indicate if changes were made.

\section{References}

Gouveia M, Strauss RP (1994) Effective federal individual income tax functions: an exploratory analysis. Natl Tax J 47:317-339 
Heathcote J, Storesletten K, Violante GL (2017) Optimal tax progressivity: an analytical framework. Q J Econ 132:1693-1754

Publisher's Note Springer Nature remains neutral with regard to jurisdictional claims in published maps and institutional affiliations. 